\title{
The Observatory on LAkes (OLA) database: Sixty years of environmental data accessible to the public
}

Frédéric Rimet, ${ }^{1 *}$ Orlane Anneville, ${ }^{1}$ Denis Barbet, ${ }^{1}$ Cécile Chardon,,${ }^{1}$ Laura Crépin, ${ }^{1}$ Isabelle Domaizon, ${ }^{1}$ Jean-Marcel Dorioz, ${ }^{1}$ Laurent Espinat, ${ }^{1}$ Victor Frossard, ${ }^{1}$ Jean Guillard, ${ }^{1}$ Chloé Goulon, ${ }^{1}$ Valérie Hamelet, ${ }^{1}$ Jean-Christophe Hustache, ${ }^{1}$ Stéphan Jacquet, ${ }^{1}$ Leslie Lainé, ${ }^{1}$ Bernard Montuelle, ${ }^{1}$ Pascal Perney, ${ }^{1}$ Philippe Quetin, ${ }^{1}$ Serena Rasconi, ${ }^{1}$ Antoine Schellenberger, ${ }^{2}$ Viet Tran-Khac, ${ }^{1}$ Ghislaine Monet $^{1}$

${ }^{1}$ UMR CARRTEL, INRAE, Université de Savoie Mont-Blanc, 75 bis Avenue de Corzent, CS 50511, 74203 Thonon-les-Bains Cedex; ${ }^{2}$ US 1106 Infosol, INRAE, 2163 Avenue de la Pomme de Pin, Ardon CS 40001, 45075 Orléans Cedex 2, France

\begin{abstract}
Lakes are essential ecosystems that provide a large number of ecosystem services whose quality is strongly impacted by human pressures. Optimal uses of lakes require adapted management practices which in turn rely on physico-chemical and biological monitoring. Long-term ecological monitoring provides large sets of environmental data. When such data are available, they have to be associated to metadata and to be stored properly to be accessible and useable by the scientific community. We present a data informatics system accessible to anyone who requests it. Maintained online since 2014 (https://si-ola.inrae.fr), it is originated from the Observatory on LAkes (OLA). It contains long-term data from 4 peri-alpine lakes (Lakes Aiguebelette, Annecy, Bourget, Geneva/Léman) and 24 highaltitude lakes of the northern French Alps. We describe the generated long-term data series, the data type, the methodologies and quality control procedures, and the information system where data are made accessible. Data use is allowed under the condition of providing reference to the original source. We show here how such a platform clearly enhances data sharing and scientific collaboration. Various studies referring to these data are regularly published in peer-reviewed journals; providing in fine a better understanding of lakes' ecosystems functioning under local and global pressures.
\end{abstract}

\section{INTRODUCTION}

While lake water represents less than $0.01 \%$ of the total water on Earth (Shiklomanov, 1993), it provides a disproportionately high number of ecosystem services, such as water provisioning, fish resources, biodiversity support, climate buffering, scenic and cultural services. Any alteration of lake's water quality has wide-ranging ecological and societal implications. In many ways, human societies depend on healthy aquatic ecosystems, and conversely, ecosystems depend on human pressures.

Corresponding author: frederic.rimet@inrae.fr

Database URL: https://si-ola.inrae.fr

Key words: physico-chemical parameters; phytoplankton; zooplankton; transparency; eutrophication; climate change.

Edited by: Aldo Marchetto, CNR-IRSA, Verbania, Italy.

Received: 16 September 2019.

Accepted: 24 February 2020.

This work is licensed under a Creative Commons Attribution NonCommercial 4.0 License (CC BY-NC 4.0).

${ }^{\circ}$ Copyright: the Author(s), 2020

Licensee PAGEPress, Italy

J. Limnol., 2020; 79(2): 164-178

DOI: 10.4081/jlimnol.2020.1944
Humans have influenced lake ecosystems for thousands of years, both locally and regionally, and impacts on the functioning of lakes often lead to alterations of water quality and modifications of ecosystem services. The most striking example is eutrophication: after industrialization and introduction of fertilizers and domestic pollutants, major changes in nutrient loads occurred in lakes, leading to increased primary production and frequent associated dysfunctions such as hypoxia and Harmful Algal Blooms (Le Moal et al., 2019). When the first symptoms of eutrophication have appeared, scientists and stakeholders promptly highlighted the need for the implementation of systematic water quality monitoring, and, at best, this type of survey began in the late 1950s.

Data collected for water quality monitoring can be used for scientific purposes and contribute to the global data collection needed for better evaluating the impacts of long-lasting changes such as climate change. Longterm data that allow to detect changes in lake ecosystems are also essential for achieving an integrated understanding of how aquatic biological populations and communities interact and to develop and test ecological theories. Long-term monitoring also help establishing reference conditions in order to identify the magnitude of changes between past and present conditions (Kaiblinger et al., 2009). Long term ecological research (LTER) programs have been established in several regions such as North America and Europe over the last decades to facilitate adapting environmental policies in watersheds and protect terrestrial and aquatic resources for future generations. 
Such programs are either national (e.g., in France: Zone Ateliers and Analysis and Experimentation on Ecosystems [AnaEE France]; in the USA: Long Term Ecological Research [LTER]) or involved in international networks (e.g., AnaEE Europe, Europe LTER, International LTER [ILTER] see Mirtl et al. 2019). These programs aim to facilitate interactions and collaborations within the multidisciplinary community of researchers such as the Global Lake Ecological Observatory Network -GLEON- (Rose et al., 2016).

Storage of long-term environmental raw data is crucial and it is essential to associate to them meta-information about data traceability. Indeed, protocols are highly susceptible to change over time because of technological improvements or natural adaptation of ecosystems. A clear description of those raw data and how they have been collected is crucial to interpret and re-use them. Consequently that information on data acquisition have to be documented in metadata which must be associated to raw data. Moreover, it is necessary to develop platforms that provide a persistent access to this information. The observatory OLA (Observatory on LAkes) offers such a structure.

The observatory OLA (https://www6.inrae.fr/soereola eng/) was created by the research unit CARRTEL (INRAE-USMB), an alpine research center devoted to the study of limnetic systems and associated food webs. It focuses on lakes of the northern French Alps and covers the region between $45^{\circ} 32^{\prime}$ and $46^{\circ} 26^{\prime}$ north. This region has been particularly affected by growing human populations and activities during the last decades. Human populations were concentrated primarily around the largest lakes (Aiguebelette, Bourget, Annecy and Geneva), where densities were particularly elevated — more than 1000 inhabitants per $\mathrm{km}^{2}$ in many places. In the $20^{\text {th }}$ century, the need to protect these precious aquatic resources became crucial because of the ecological, social and economic importance of these four lakes. Therefore, an ecological monitoring started in the 1960's as soon as the first signs of important eutrophication occurred (Jacquet et al., 2014a; Montuelle and Clemens, 2015; Tab. 1). These monitorings are still ongoing today and are funded through various administrative entities, representing several municipalities neighboring the lakes (see Supplemental data S1 for details).

OLA provides high-quality scientific data for understanding and modeling the ecological functioning of lakes.
Data are publicly available and are regularly used in scientific studies. An information system (IS) accessible at https://si-ola.inrae.fr gives access to the data. In this paper, we briefly describe the analytical methods for the main parameters, the database content, rules for using the data, IS data storage and the website interface.

\section{Data available in the database}

The efficient partnership between scientists and local stakeholders allowed the collection of physical, chemical and biological data from 1957 on Lake Geneva (also called Lake "Léman"), 1966 on Lake Annecy, 1974 on Lake Aiguebelette and 1987 on Lake Bourget. More recently, since the late 90s, 24 small high-altitude lakes situated on a latitudinal gradient in the French Alps were included in the observatory, and are since then monitored. Studying these lakes, considered as 'pristine' and highly sensitive to climate change, opens perspectives on the impacts of global change on lake functioning. The location and intrinsic physical characteristics of the largest lakes monitored in the framework of OLA are shown in Tab. 1 and Fig. 1. Samples are collected from the middle of the lake above its deepest point. Detailed description of all sampling stations can be found at https://si-ola.inrae.fr and in Tab. 2.

\section{ACQUISITION OF BIOLOGICAL DATA}

\section{Taxonomic composition of phytoplankton community}

The water sample for phytoplankton taxonomic identification and counting is collected within the first $20 \mathrm{~m}$ (0-10 or $0-18 \mathrm{~m}$, depending on the lake and year) using an integrated sampling bottle. Samples are preserved with Lugol and then are kept in a dark and cool place until microscopic observations are performed. The Utermöhl technique (Utermöhl, 1958), standardized at the European level (CEN, 2006), is used. Briefly, after the settling of a known volume of sample in a microscopic chamber, algal counts and determinations are carried out under an inverted microscope at x64 magnification using specialized literature (for instance, the various volumes of the Süsswasserflora von Mitteleuropa edited by B. Büdel, G. Gärtner, L. Krienitz and M. Schagerl). Results are expressed in biovolume per volume of water $\left(\mu \mathrm{L} . \mathrm{m}^{-3}\right)$ or in biomass

Tab. 1. Limnological characteristics of the main lakes monitored in the OLA observatory.

\begin{tabular}{|c|c|c|c|c|}
\hline Lake & Volume $\left(\mathrm{km}^{3}\right)$ & Renewal time (years) & Max depth (m) & Watershed surface $\left(\mathrm{km}^{2}\right)$ \\
\hline Geneva & 89 & 11.3 & 310 & 7395 \\
\hline Bourget & 3.6 & 9.0 & 145 & 560 \\
\hline Annecy & 1.12 & 3.8 & 82 & 251 \\
\hline Aiguebelette & 0.116 & 3.1 & 70 & 59 \\
\hline
\end{tabular}


per volume of water considering that phytoplankton density is $1 \mathrm{~kg} . \mathrm{L}^{-1}\left(\mu \mathrm{g} . \mathrm{L}^{-1}\right)$. A database of species biovolumes (Rimet and Druart, 2018) is used to obtained these results. Over more than 50 years, this biovolumes' database has been regularly updated to include species observed in the alpine lakes in France (Lakes Geneva, Annecy, Bourget and Aiguebelette) and also in high-altitude lakes in the French Alps (Feret et al., 2017) and in various other French lakes.

Simultaneously, picocyanobacteria are examined in Lakes Annecy, Bourget and Geneva from samples taken at 6 discrete depths since 2003 (see details in supplemental data $\mathrm{S} 2$ ); these data will be included in the IS in the forthcoming years.

\section{Primary production and $\mathrm{Chl} \boldsymbol{a}$}

Primary production and $\mathrm{Chl} a$ are measured at 9 discrete depths $(0,1,2.5,3.5,5,7.5,10,15$ and $20 \mathrm{~m})$ in Lake Geneva (two times a month the entire year except once a month from December to February). Primary production has been measured using the ${ }^{14} \mathrm{C}$ method (Steemann-Nielsen, 1952) with the incorporation of $\mathrm{NaH}^{14} \mathrm{CO}_{3}$

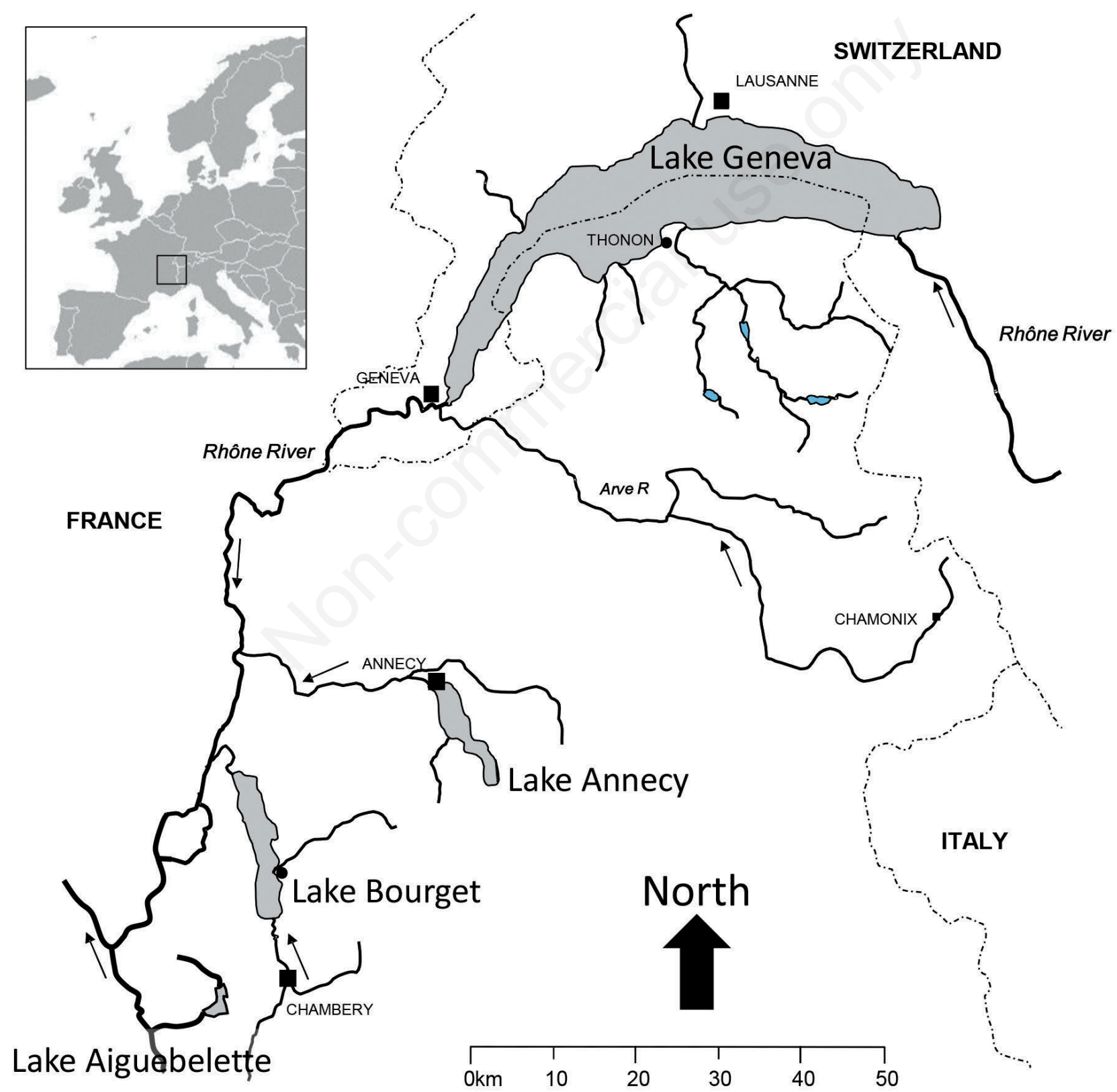

Fig. 1. Location of the large peri-alpine lakes monitored in the OLA observatory. Arrows indicate the flow of the main rivers. 
from 1971 to 2012 (Pelletier, 1983). Since 2012, measurements of primary production are carried out using an isotopic method (incubation with ${ }^{13} \mathrm{C}$ sodium bicarbonate whose incorporation into the biomass is measured by isotope mass spectrometry). Measures of primary production are expressed in $\mu \mathrm{g} \mathrm{C} / \mathrm{L} / \mathrm{h}$. Chlorophyll $a$ is analyzed using spectrophotometry after extraction into $90 \%$ acetone (ISO 10260: 1992). Chlorophyll $a$ discrete measurements are completed with vertical profiles measures obtained with multiparameter probes.

\section{Zooplankton}

Zooplankton is sampled with a vertical tow from 50 $\mathrm{m}$ to the surface using a $200-\mu \mathrm{m}$ plankton net for crustaceans and a $64-\mu \mathrm{m}$ plankton net for rotifers. Samples are fixed in the field using $5 \%$ buffered formaldehyde.

Crustacean identification and counts are carried out in a subsample of a known volume of the net sample using a light microscope at $\mathrm{x} 10$ magnification. The identification books of Amoros (Amoros, 1984) and Dussart (Dussart, 1967, 1969) are used to distinguish species. Larger organisms (Leptodora kindtii Focke and Bythotrephes longimanus Leydig) are identified using the same procedure at $x 4$ magnification. Final results are given in number of individuals per square meter.

Samples dedicated for observing rotifers are processed following the Utermöhl technique (Utermöhl, 1958). A subsample of known volume is allowed to settle in a microscopic chamber, and counts and determinations are carried out using an inverted microscope at x16 magnification. The identification books of Stemberger (Stemberger, 1979) and Voigt and Koste (Voigt and Koste, 1978a, 1978b) are used to distinguish species. Results are given in number of individuals per square meter.

Tab. 2. Complete list of the lakes and sampling stations integrated in the OLA.

\begin{tabular}{|c|c|c|c|c|c|}
\hline Type & Name of lake & Name of sampling station & Latitude & Longitude & Altitude (m) \\
\hline Large lake & Aiguebelette & Point a & 45.55066 & 5.00900 & 390 \\
\hline Large lake & Annecy & Grand lac & 45.87270 & 6.16453 & 447 \\
\hline Large lake & Annecy & Petit lac & 45.81748 & 6.22140 & 447 \\
\hline Large lake & Bourget & 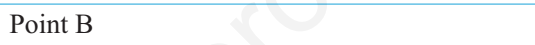 & 45.75583 & 5.86000 & 231 \\
\hline Large lake & Léman & Shl2 & 46.45345 & 6.59423 & 372 \\
\hline High-lake & Anterne & Sampling point 1 & 45.99063 & 6.79889 & 2063 \\
\hline High-lake & Arpont & Sampling point 1 & 45.31580 & 6.77683 & 2672 \\
\hline High-lake & Aumar & Aumar : sampling point 1 & 42.84250 & 0.14972 & 2192 \\
\hline High-lake & Blanc du Carro & Sampling point 1 & 45.42000 & 7.12668 & 2753 \\
\hline High-lake & Bresses inférieur & Centroïd & 44.15812 & 7.24204 & 2458 \\
\hline High-lake & Bresses supérieur & Centroïd & 44.15932 & 7.24406 & 2501 \\
\hline High-lake & Brévent & Sampling point 1 & 45.92906 & 6.82739 & 2127 \\
\hline High-lake & Corne & Sampling point 1 & 45.22490 & 6.07870 & 2098 \\
\hline High-lake & Cornu & Sampling point 1 & 45.95837 & 6.84954 & 2275 \\
\hline High-lake & $\operatorname{Cos}$ & Sampling point 1 & 45.23250 & 6.07890 & 2183 \\
\hline High-lake & Izourt & Izourt : sampling point 1 & 42.68805 & 1.49777 & 1645 \\
\hline High-lake & Jovet & Sampling point 1 & 45.75697 & 6.73199 & 2173 \\
\hline High-lake & Lauzanier & Sampling point 1 & 44.3791 & 6.87234 & 2280 \\
\hline High-lake & Malrif & Centroïd & 44.82292 & 6.86922 & 2580 \\
\hline High-lake & Merlet Supérieur & Sampling point 1 & 45.36040 & 6.64023 & 2447 \\
\hline High-lake & Mont Coua & Sampling point 1 & 45.31740 & 6.63899 & 2666 \\
\hline High-lake & Muzelle & Sampling point 1 & 44.95050 & 6.09722 & 2099 \\
\hline High-lake & Noir du Carro & Sampling point 1 & 45.42140 & 7.12491 & 2750 \\
\hline High-lake & Pavé & Centroïd & 44.98770 & 6.32588 & 2846 \\
\hline High-lake & Pétarel & Centroïd & 44.80214 & 6.16875 & 2090 \\
\hline High-lake & Pisses & Centroïd & 44.72245 & 6.37941 & 2515 \\
\hline High-lake & Plan Vianney & Sampling point Edytem & 44.95750 & 6.04333 & 2250 \\
\hline High-lake & Pormenaz & Sampling point 1 & 45.96254 & 6.79460 & 1947 \\
\hline High-lake & Rabuons & Sampling point 1 & 44.26970 & 6.98250 & 2501 \\
\hline River & Dranse & Defaut dranse - main tributary of Lake Léman & 46.38350 & 6.50744 & 388 \\
\hline
\end{tabular}




\section{PHYSICAL AND CHEMICAL DATA ACQUISITION}

\section{In situ measurements}

Transparency, using a Secchi disk, is systematically measured following the international standard ISO 7027. Probes are used to measure depth (pressure), $\mathrm{pH}$, conductivity, oxygen concentration, turbidity, in situ chlorophyll $a$ fluorescence and photosynthetic active radiation. In recent years, the most commonly used probes were CTM214 FO and CTD009 (Sea and Sun Technology ${ }^{\odot}$ ).

Water samples are collected at discrete depths for subsequent chemical and physical laboratory analyses. Sampling is performed using bottles such as the Freeflow bottle $\left(\right.$ Hydrobios $^{\odot}$ ) or the integrated sampling bottle (Hydrobios ${ }^{\odot}$ IWS bottle). In past years, other kinds of bottles were used, including the Niskin bottle for sampling at discrete depths and the Pelletier bottle for collecting integrated depth samples (Pelletier and Orand, 1978).

\section{Chemical and physical laboratory data}

In the laboratory, water samples are filtered immediately through Whatman ${ }^{\circ} \mathrm{GF} / \mathrm{F}$ filters $(0.7-\mu \mathrm{m}$ nominal pore size) and then stored at $4{ }^{\circ} \mathrm{C}$ in high-density polyethylene plastic bottles or amber glass bottles until analyses, which are performed within $48 \mathrm{~h}$ after collection. A large range of physical and chemical analyses are carried out following international or national standards. Chemical procedures follow rigorous quality assurance and control to ensure the quality of obtained analytical data. Tab. 3 shows the major analyses performed.

Total suspended matter is determined using an ultramicro balance (XP2U; Mettler Toledo $\odot$ ). Major cations $\left(\mathrm{Ca}^{2+}, \mathrm{Mg}^{2+}, \mathrm{K}^{+}\right.$and $\left.\mathrm{Na}^{+}\right)$are determined using flame (acetylene/air) atomic absorption spectrophotometry (AA240FS; Varian ${ }^{\odot}$ ) following NF 90-020. Lanthanum is added as a matrix modifier to minimize interference. Major anions $\left(\mathrm{Cl}^{-}, \mathrm{NO}_{3}{ }^{-}\right.$and $\left.\mathrm{SO}_{4}{ }^{2-}\right)$ are quantified using ion exchange (861 Advanced Compact ion chromatograph; Metrohm ${ }^{\circ}$ ) with chemical suppression following ISO 10304-1.

An automatic titrator (Basic Titrino 794, Metrohm ${ }^{\circ}$ ) with a glass electrode is used to perform successive $\mathrm{pH}$ measurements. Temperature corrections are systematically applied when performing lab measurements of the conductivity (ISO 10523:2008). Total alkalinity is obtained using potentiometric titration (ISO 9963-1).

A UV-vis spectrophotometer (Cary 50 scan; $\operatorname{Varian}^{\circ}$ ) is used to determine total phosphorus and orthophosphate based on sulfuric acid digestion and a molybdenum blue method (EPA 365.3). Ammonium is determined based on an indophenol blue method (ISO 5664:1984), and nitrite ions are determined using a diazotization method (ISO 6777:1984).

Total nitrogen is determined using chemiluminescence after high-temperature digestion and catalytic postcombustion using an ElementarVario ${ }^{\circ} \mathrm{TOC} / \mathrm{TNb}$ coupled with a chemiluminescence detector (APNA-370; $\mathrm{Horiba}^{\circ}$ ). Total inorganic nitrogen (ammonium and nitrate ions) is calculated as the difference between total nitrogen and or-

Tab. 3. Physical and chemical analyses carried out in the laboratory. References to the standard methods and to the main principles are given.

\begin{tabular}{|c|c|c|}
\hline Parameters & Standard & Principle \\
\hline $\mathrm{pH}$, Conductivity & ISO $10523: 2008$ & Potentiometric and conductometric measure \\
\hline Alkalinity & ISO 9963-1 & Potentiometric determination \\
\hline Total suspended matter & EN 872:2005 & Filtration \\
\hline Dissolved oxygen & ISO 5813:1983 & Iodomitric method \\
\hline Total and dissolved organic carbon & EN 1484:1997 & Heated-Persulfate oxidation, Non-dispersive infrared measure \\
\hline Particulate carbone and nitrogen & ASTM D2579-93e1 & $\begin{array}{l}\text { CHN elemental analyzer (High-temperature combustion method, } \\
\text { gaz chromatography, thermal conductivity detector) }\end{array}$ \\
\hline Ammonium & ISO 5664:1984 & UV-Visible spectrometer \\
\hline Nitrite & ISO 6777:1984 & UV-Visible spectrometer \\
\hline Nitrate, chloride, sulfate & ISO $10304-1$ & Ion chromatography \\
\hline Total nitrogen & EN 12260:2003 & $\begin{array}{l}\text { High temperature digestion and catalytic post combustion, } \\
\text { chemiluminescence measure }\end{array}$ \\
\hline Orthophosphate, total phosphorus, particulate phosphorus & EPA 365.3 & UV-Visible spectrometer \\
\hline Silica & NF T 90-007 & Discret Chemistry Analyzer \\
\hline Majors cations (sodium, potassium, calcium, magnesium) & NF 90-020 & Atomic Absorption Spectrometry \\
\hline Chlorophyll-a & ISO $10260: 1992$ & UV-Visible spectrometer \\
\hline
\end{tabular}


ganic nitrogen (EN 12260:2003). Total and dissolved organic carbon are measured using a non-dispersive infrared detector coupled to an Aurora $1030 \mathrm{~W}$ carbon analyzer, applying a heated persulfate oxidation method (EN 1484:1997). Dissolved organic carbon is determined from filtered (muffled Whatman ${ }^{\circ}$ GF/F filter) samples. Particulate organic carbon and nitrogen are analyzed applying a high-temperature combustion method (ASTM D257993e1) with a gas chromatograph equipped with a thermal conductivity detector (Flash 2000; Thermoscientific ${ }^{\circ}$ ). Biogenic silica is analyzed using a Smartchem 200 Discrete Analyzer (WESTCO Scientific Instruments $\odot$ ), applying NF T90-007.

\section{DATA STORED IN THE IS: \\ FOCUS ON A SELECTION OF LONG-TERM LIMNOLOGICAL DATA}

Tab. 4 gives an overview of the data available in the IS. The longest series of data are available for Lake Geneva (going back to 1957 for chemical parameters).
The most recent series are available for the high-altitude lakes. A detailed description of the data is available at https://si-ola.inrae.fr/

From such data, the responses of lakes to local and global pressures have been described, as for instance the effect of global warming on water temperature (O'Reilly et al., 2015), thermal structures (Kraemer et al., 2015), lake mixing, oxygen availability (Foley et al., 2012), plankton communities and fisheries (O'Reilly et al., 2003). Local and global pressures deeply modify alpine lake functioning and biodiversity, as testified by recent paleo-reconstructions showing multi-level responses in biodiversity facing eutrophication and warming (Perga et al., 2015).

Here we selected some of these long-term data to illustrate some of the scientific advances they recently provided. Supplemental data 2 and 3 show complementary data collected for other biological compartments (fish and picophytoplankton) that will be included soon in the OLA-IS.

Tab. 4. Temporal distribution of the data available in the information system (white: no data, grey: data available in the information system).

\begin{tabular}{|c|c|c|c|c|c|c|c|c|c|}
\hline Lake & Measures & 50ies & $60 \mathrm{ies}$ & 70 ies & 80 ies & 90ies & 2000 & 2010 & Present \\
\hline \multirow[t]{4}{*}{ Aiguelebette } & Chemical par. & & & 1974 & & & & & \\
\hline & Multipar. probe & & 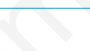 & 1974 & & & & & \\
\hline & Phytoplankton & & 8 & & & 1998 & & & \\
\hline & Chlorophyll & 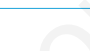 & & & 1989 & & & & \\
\hline \multirow[t]{5}{*}{ Annecy } & Chemical par. & 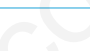 & 1966 & & & & & & \\
\hline & Multipar. probe & 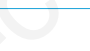 & 1966 & & & & & & \\
\hline & Zooplankton & & & & & 1994 & & & \\
\hline & Phytoplankton & & & & & 1996 & & & \\
\hline & Chlorophyll & & & & & 1990 & & & \\
\hline \multirow[t]{5}{*}{ Bourget } & Chemical par. & & & & & 1999 & & & \\
\hline & Multipar. probe & & & & & & 2003 & & \\
\hline & Zooplankton & & & & & 1995 & & & \\
\hline & Phytoplankton & & & & & 1995 & & & \\
\hline & Chlorophyll & & & & 1987 & & & & \\
\hline \multirow[t]{5}{*}{ Geneva } & Chemical par. & 1957 & & & & & & & \\
\hline & Multipar. probe & 1957 & & & & & & & \\
\hline & Zooplankton & 1959 & & & & & & & \\
\hline & Phytoplankton & & & 1974 & & & & & \\
\hline & Chlorophyll & & & 1976 & & & & & \\
\hline High & Chemical par. & & & & & 1992 & & & \\
\hline Altitude & Multipar. probe & & & & & & & 2014 & \\
\hline \multirow[t]{3}{*}{ Lakes* } & Zooplankton & & & & & & & 2015 & \\
\hline & Phytoplankton & & & & & 1998 & & & \\
\hline & Chlorophyll & & & & & & & 2015 & \\
\hline
\end{tabular}

*High altitude lakes encompass: Anterne, Arpont, Aumar, Blanc du Carro, Bresses inférieur, Bresses supérieur, Brévent, Corne, Cornu, Cos, Izourt, Jovet, Lauzanier, Malrif, Merlet supérieur, Mont Coua, Muzelle, Noir du Carro, Pavé, Pétarel, Pisses, Plan Vianney, Pormenaz, Rabuons. 


\section{Interannual dynamics of phosphorus in deep peri-alpine lakes}

Lakes Geneva, Bourget, Annecy and Aiguebelette are typologically similar but they have been impacted differently by local anthropogenic pressures. Restoration of these lakes, after phosphorus pollution several decades ago, provides nowadays exemplary cases of successful restoration of trophic status in a world where freshwater eutrophication is increasing globally (Le Moal et al., 2019). Lakes Geneva and Bourget, and to a lesser degree, Annecy and Aiguebelette, underwent rapid eutrophication during the $60 \mathrm{~s}$ and 70 s as a result of development of nutrient point sources, mostly untreated domestic effluent discharges. The temporal series of total phosphorus concentrations in Lake Geneva from 1957 to 2017, in Lake Bourget from 19992017, in Lake Annecy from 1966 to 2017 and in Lake Aiguebelette from 1974 to 2017 are shown in Fig. 2.

Phosphorus maxima observed in the data were reached during the late 70 s in Lake Geneva and during the 90s in Lakes Annecy and Aiguebelette. The maximum phosphorus concentration in Lake Bourget during the $80 \mathrm{~s}$ is also well known but not included in the database (Perga et al., 2015). Effective measures for reducing the phosphorus load in the 70 s resulted in strong decreases in phosphorus concentrations in the four large alpine lakes. Re-oligotrophication processes continue today (Jacquet et al., 2014a).

\section{Long-term chloride concentration in Lake Geneva}

Chloride ion concentration in Lake Geneva increased continuously from 1973 to 2017 (Fig.3). The annual average concentration reached $10.31 \mathrm{mg} \mathrm{Cl}^{-} / \mathrm{L}$. The contributions of various tributaries to the lake largely explain this trend (Klein, 2016). Chloride concentration reflects a growing utilization of chemical chlorine-based products in the industrial sector (metallurgy and pharmaceutical sectors) and the application of deicing salt during winter (Gumy and De Alencastro, 2001). These data have been used to consolidate a database of 529 lakes in Europe and North America (Dugan et al., 2017b); the associated study predicts that many lakes could exceed the aquatic life threshold criterion for chronic chloride exposure $(230 \mathrm{mg}$ $\mathrm{L}^{-1}$ ), stipulated by the US Environmental Protection Agency (EPA), in the next 50 years if current trends do continue (Dugan et al., 2017a).

\section{Temporal dynamics of phytoplankton and zooplankton in Lake Geneva}

Over the last 50 years, the abundance, taxonomic structure and phenology of phytoplankton communities have changed (Anneville and Leboulanger, 2001; Anneville et al., 2005, 2010, 2018; Rimet et al., 2009; Jacquet et al., 2014c) because of decrease in phosphorus concentrations, warming in water temperature and change

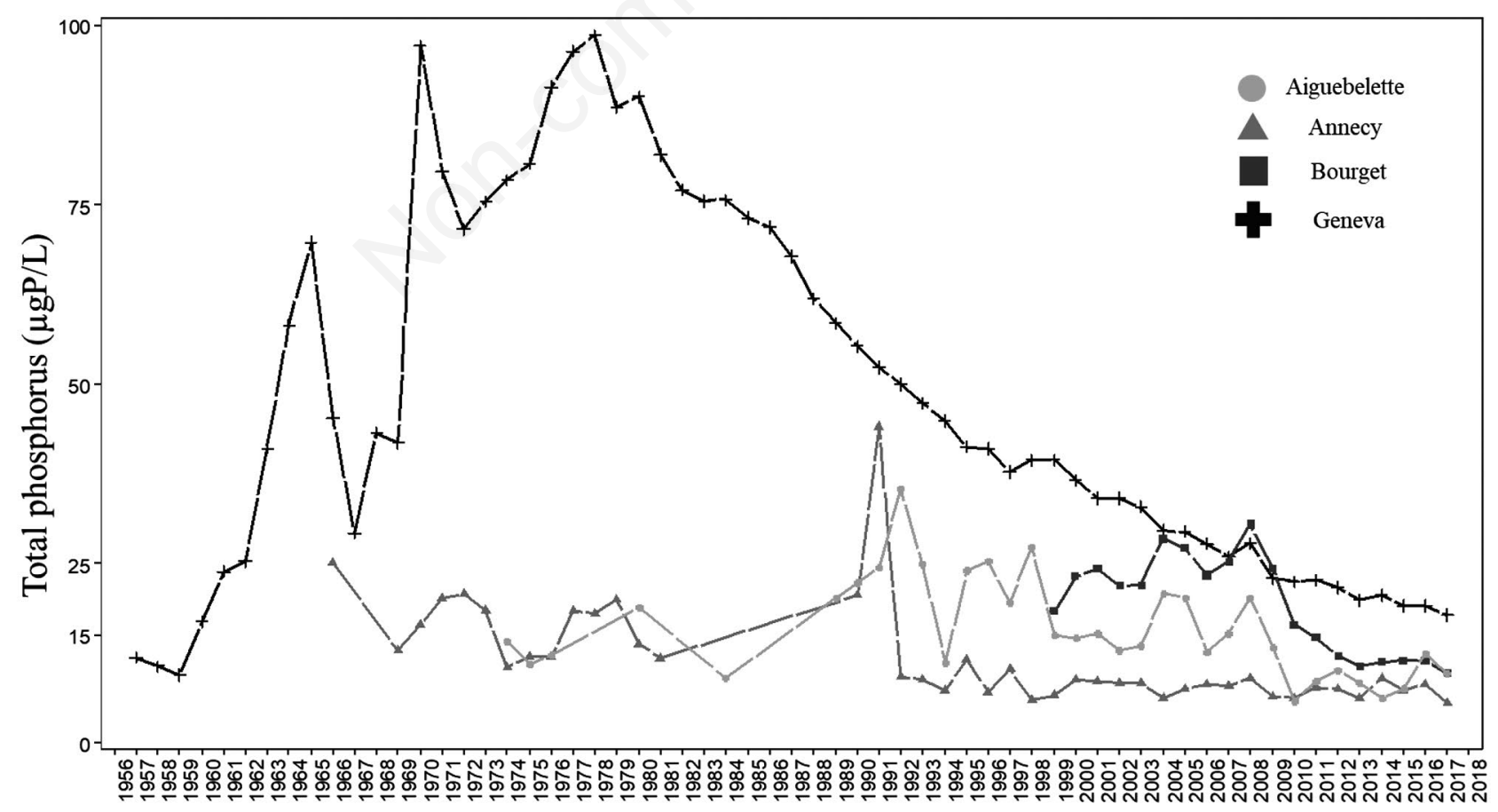

Fig. 2. Interannual dynamic of total phosphorus in the large alpine lakes: Aiguebelette (1974-2017), Annecy (1966-2017), Bourget (1999-2017) and Geneva (1957-2017). 
in the thermal stratification dynamic. Except in Lake Geneva (Fig. 4), phytoplankton biomass has systematically decreased with phosphorus concentration. The unexpected trend in phytoplankton biomass observed in Lake Geneva is explained by a decrease in zooplankton grazing (Tadonleke et al., 2009), a change in phytoplankton taxonomic composition and an increase in phytoplankton biomass during winter and spring as a result of temperature increases during these seasons (Anneville et al., 2018). Moreover, the abundance and taxonomic composition in zooplankton gradually changed with time because of decreases in food quality (Anneville et al., 2007 showed a shift from herbivorous to carnivorous copepods), changes in thermal conditions (Molinero et al., 2007) and trophic status (Molinero et al., 2006), and increased fish predation (Nõges et al., 2018).

\section{Changes in phytoplankton composition}

Long-term monitoring of phytoplancton in Lake Geneva is one of the longest time series in the world (Fig. 5). It shows deep changes in its biomass and moreover on its taxonomic composition from the 70ies to nowadays. These changes were mostly controlled by bottom-up factors, such as nutrient level. For instance, the decrease of Dinophyceae from 1974 is mostly due to Ceratium hirundinella, a species preferring eutrophic epilimnia
(Reynolds et al., 2002) and which is nowadays quite rare in Lake Geneva phytoplankton compared to 40 years before. On the other hand, some species known to prefer oligotrophic waters and which have mixotrophic capacities (Padisak et al., 2009), mostly belonging to the Chrysophyceae (e.g. Dinobryon spp., Kephyrion spp., Chrysolykos planktonicus) showed an increase in their biomass and are common in the summer epilimnion of the last decade, whereas they were absent in the 70ies. Inside the diatom class, some species have disappeared, like Stephanodiscus binderanus, a centric usually observed in eutrophic waters, and have been replaced by species like Cyclotella costei, characterizing re-oligotrophication stage in Lake Geneva (Rimet et al., 2009). Global warming has an impact on lake stratification and phytoplankton composition; it is the case with Mougeotia gracillima, a filamentous Zygophyceae which showed higher biomass in the metalimnion after year 2000, sometimes blooming when a thick layer of the epilimnion is stratified (Tapolczai et al., 2015).

Such changes in the phytoplanktonic structure and biomass have also been observed in Lake Bourget. During almost 20 years, the toxic and filamentous cyanobacteria Planktothrix rubescens developed and bloomed (representing between $20 \%$ and more than $50 \%$ of the algal biomass each year) despite efforts to reduce phos-

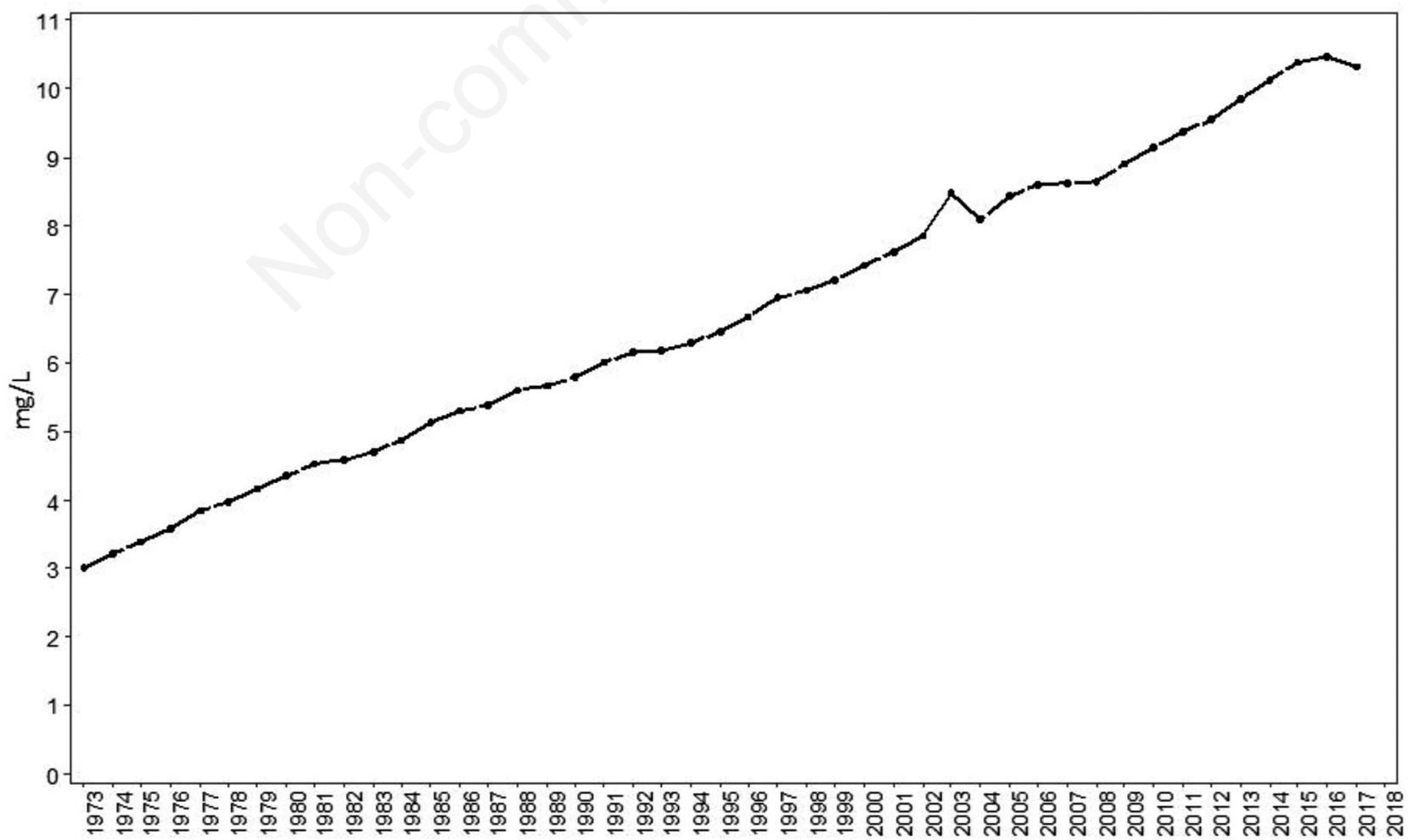

Fig. 3. Interannual dynamic of chloridein Lake Geneva between 1973 and 2017. 
phorus loading since the early 1980's. Between 1996 and 2009 blooms occurred and persisted while the lake was mesotrophic. By the end of 2009, however, a conjunction of events occurred so that the cyanobacterium disappeared. Interactions among nutrients, light availability, temperature and water column stability as well as zooplankton grazing could be identified as important factors for explaining bloom collapse (Jacquet et al., 2014b). In parallel, as for the Lake Geneva, mixotrophic algal species and picophytoplankton groups have significantly increased during the last decade in response to the re-oligotrophication and the disappearance of P. rubescens. It is noteworthy, however, that 2016 and 2017 constituted again two years where the species raised again despite nearly oligotrophic conditions (Jacquet et al., 2018).

\section{INFORMATION SYSTEM STRUCTURE}

The OLA-IS is built around generic components offering common functionalities to various observatories dedicated to a variety of environmental topics (lakes, grasslands, forests and crops) (Schellenberger et al., 2019b; https://doi.org/10.15454/QJJJZU). However, several features dedicated specifically to lakes were added (specific datatype modules), making the OLA-IS specific (Schellen- berger et al., 2019a; https://doi.org/10.15454/VBWYWG). The OLA-IS was written in Java as a Maven project and is divided into several lake datatype modules. The OLA database was designed according to a relational model (Monet et al., 2020a, https://doi.org/10.15454/OHXVJY) managed by PostgreSQL Release 12. Technically, the database has been designed to make the modeling as generic as possible so that each type of data (for instance: phytoplankton data type, probes data type, etc.) is modeled in the same way. In addition, the metadata tables are the same regardless of the type of data studied.

The web interface is based on the JSF framework, and Primefaces, Spring and Hibernate graphics components libraries complement the technologies. The IS is accessed online through an apache server (https://si-ola.inrae.fr).

The interface provides information on the available data and states the Terms of Use (ToU) as stipulated in the data access license (Monet et al., 2020b, https://doi.org/ 10.15454/HHN2GA). Both the interface and the data content (variable names, units, etc.) are available in English and French.

The interface proposes extraction by data type. For each data type, the user can choose the lake, the time period and the desired variables. After extraction is complete, the user can download the data as text (.cvs) files. Online notifications show the user if the extraction is in progress or completed, and this does not imply the user

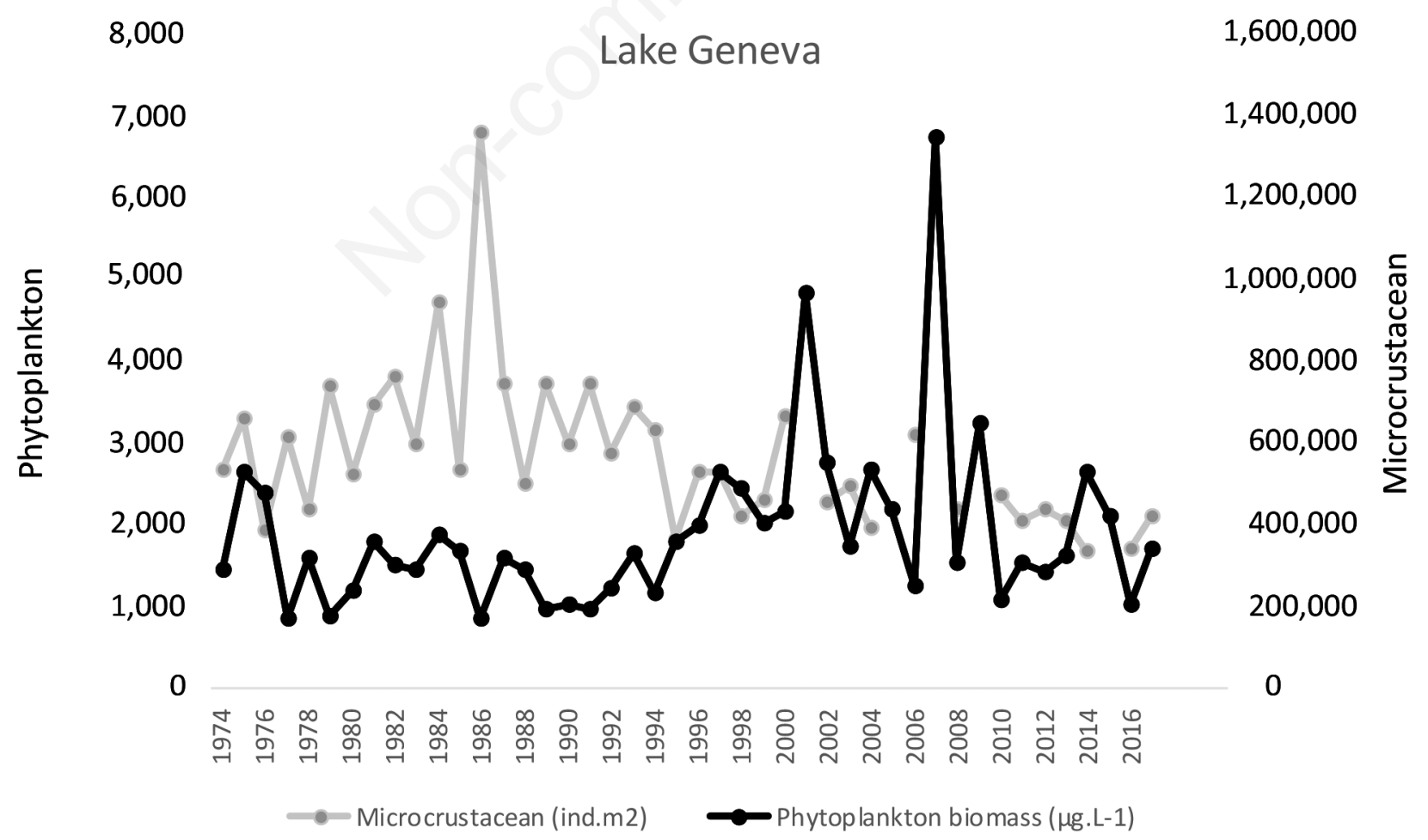

Fig. 4. Interannual dynamic of phytoplankton $\left(\mu \mathrm{g} . \mathrm{L}^{-1}\right)$ and microcrustacean (ind.m2) biomasses in lake Geneva. 
must remain logged in. Another interface, restricted to administrators, enables management of the users, the rights granted to them, and control, deposit and publication of validated data.
OLA is part of the French national research infrastructure Anaee-f . Anaee-f works to publish its metadata and its data through the use of the semantic web (https://www.anaee-france.fr/en/infrastructure-services/

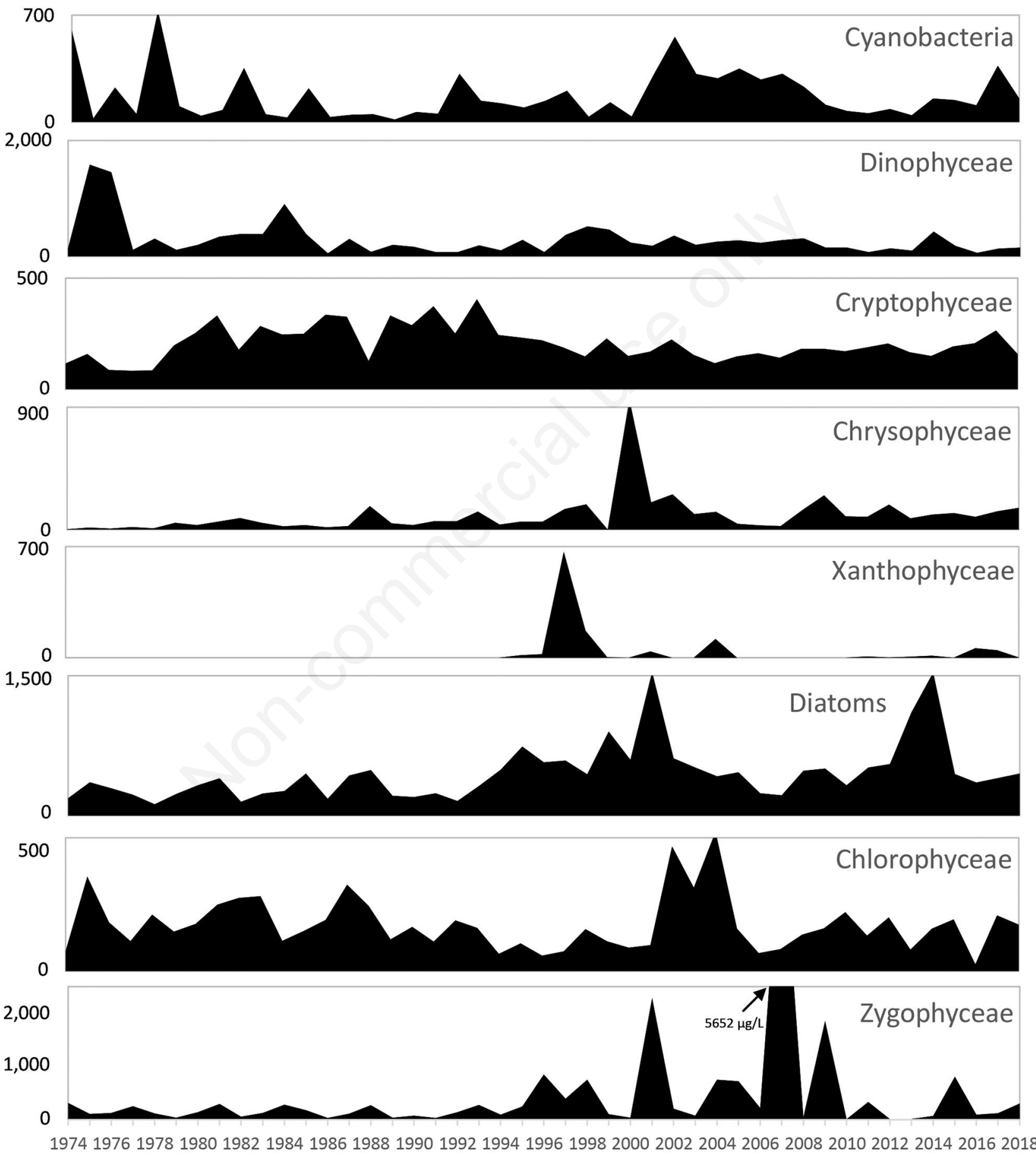

Fig. 5. Taxonomic composition of lake Geneva phytoplancton expressed in biomass ( $\mu \mathrm{g} / \mathrm{L}$ ) from 1974 to 2018 (each value is an annual mean of the water column integrated phytoplankton samplings carried out 2 times a month except once a month between December and February). 
modelling-and-data/semantic-reference-framework). OLA fits in with this perspective and uses the vocabulary of thesaurus Anaee-F, data are semantically annoted using the AnaEE-F (http://agroportal.lirmm.fr/ontologies/ ANAEETHES and OBOE ontologies (Madin et al., 2007). In this way, OLA IS is developed according to FAIR Data principles (Findable, Accessible, Interoperable, Re-usable) (Clobert et al., 2018; Pichot, 2017, Wohner et al., 2019).

\section{DATA MANAGEMENT PLAN}

Development and implementation of adapted policies and processes are essential to maintain the integrity, security and usability of the data. Data validation, data access and sharing policy are important component of the data management plan.

\section{Quality control}

The OLA-IS contains only curated data. All along the data collection, from field sampling to data archiving, rigorous quality controls are carried out (Fig. 6). These data follow a controlled vocabulary included in the AnaEE France thesaurus (Clastre et al., 2018).

\section{DATA ACCESS AND SHARING POLICY}

Before downloading and using the data, a user must register on the SI, agree to the GCUs and formulate the data request. The data request is evaluated by the OLA scientific committee (scientists of the research unit CARRTEL). Once the request is validated, the user is provided a login which allow to enter the OLA-IS for a period of three months and download the data. Access to the IS and the GCUs is available at https://si-ola.inrae.fr/. The GCUs describe the rights and obligations of the user when using the data provided by the OLA-IS. Data are accessible free of charge via registration on the website and compliance with the GCUs. The data are protected under copyright law, and compliance with the GCUs will not change this. All the data stored in the OLA-IS are usable by any applicant, under the condition of providing reference to the original source of the data in any communication by indicating the lake(s) studied, as given in the GCUs and by citing the present paper:

Rimet et al. (2020) The Observatory on LAkes (OLA) database: Sixty years of environmental data accessible to the public.

Furthermore, the user is asked to transmit to the OLAIS manager a copy of the work wherein the downloaded data were analyzed and valorized. The GCUs expire after a period of five years after which the user must destroy the data. The user must formulate a new request in case the data are required for a new project. Data cannot be shared or stored in another public database.

\section{CONCLUSIONS AND PERSPECTIVES}

Since the OLA-IS was created in December 2014, an average of more than one peer-reviewed publication providing limnological data from the OLA has been accepted monthly. More than 55 publications have been referenced on Google Scholar from 2015 to 2018. This also corresponds to the monthly data demands received through the OLA-IS website. It is obvious that this website and IS fuel data-sharing and scientific collaborations between environmental scientists. Proof of this is found in large international co-authorships of several papers that include OLA data. Examples are Sharma et al. (2015), where several tens of scientists studied surface lake temperatures, Taranu et al. (2015), where cyanobacteria increases along with nutrient concentrations were studied on a large temporal and spatial scale, and Leach et al. (2018), where the relative importance of light and thermal stratification were found to be key drivers of deep chlorophyll maxima structure in a variety of lakes. Other examples include studies of the impact on stratification and response to climate change of lake morphometry (Kraemer et al., 2015), the rise in chloride concentrations in European and American lakes (Dugan et al., 2017b), or the widespread diminishing anthropogenic effects on calcium in freshwaters because of industrial acid depositions (Weyhenmeyer et al., 2019).

However, even if the OLA-IS is an excellent platform for data accessibility, the inclusion of new types of data must be scheduled. Some of these new types of data are related to technological evolutions that enable highthroughput data (DNA high-throughput sequencing and high-frequency sensors) to be accessed. Until now, biological analyses have been carried out under microscopes (e.g., for phytoplankton and zooplankton), requiring experts trained in taxonomical recognition. An alternative is DNA barcoding (Hebert et al., 2003) and high-throughput-sequencing, which enables rapid analyses of many environmental samples at lower costs compared to the involvement of specialized analysts. This method was tested on mock communities of algae (Kermarrec et al., 2013) and then on natural algal communities (Vasselon et al., 2017; Rivera et al., 2018). It also enables global assessments of protist diversity, including rare biosphere (Taib et al., 2013) and small eukaryotes whose taxonomy remains still not well-established (Lepere et al., 2008; Mangot et al., 2013). Therefore assessments of diversity are enlarged compared to the restricted diversities observable using optical devices. Such methodologies can also be applied to fish (Pont et al., 2018) and macroinvertebrates (Elbrecht et al., 2017), also providing promising results. The OLA lakes are already studied using metabar- 


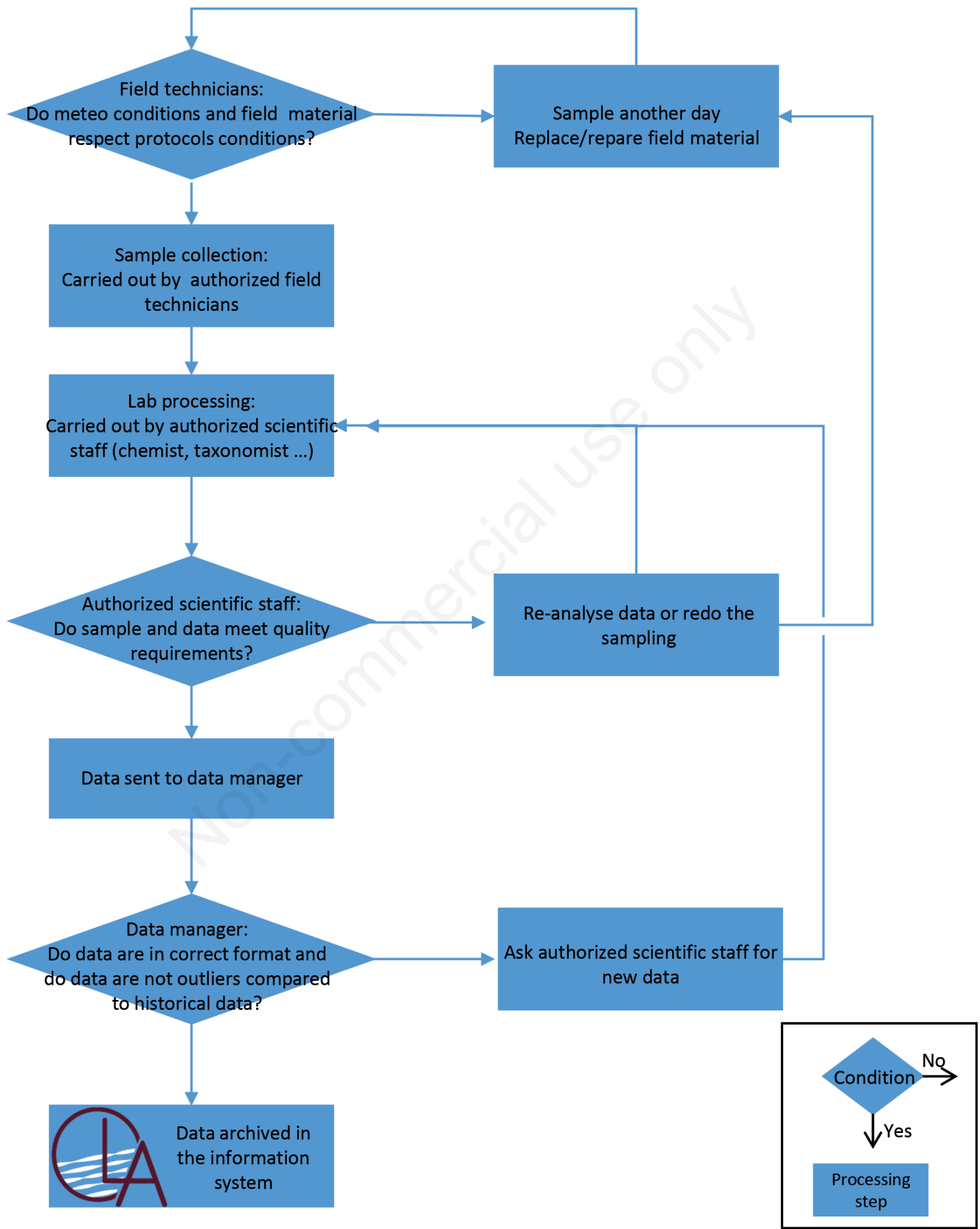

Fig. 6. Simplified flow chart for data validation and curation before integration in the OLA information system. 
coding for algal communities (Rivera et al., 2018; Rimet et al., 2018; Lefrançois et al., 2018), global protist diversity (Lepere et al., 2008) and fish (Civade et al., 2016). Therefore, genomic data storage in the OLA-IS must be envisaged. However, the quantity of data stored will increase several orders of magnitude with the changes from classical to these more sophisticated methods (Keck et al., 2017), and informatics solutions will be required.

High-throughput data storage (and accessibility) also presents an imminent challenge related to the development and storage of data from high-frequency sensors. Recent technological developments have increased the number of variables monitored in lakes using automatic high-frequency sensors (Marcé et al., 2016). To facilitate posterior data handling and interpretation, it is critical that an interface as the OLA-IS provides storage capacity and sharing access for this type of data, given it is becoming essential in near-future limnological surveys.

Monitoring additional matrices and habitats in lakes and their integration into the OLA-IS are already envisaged. For instance, data on fish populations, picocyanobacteria and new sampled habitats such as the littoral zone, are now routinely collected and are planned to be archived in the OLA-IS whose architecture allows to host new data. Therefore, integrating high-throughput data (DNA and sensors), new sampling sites and matrices into the OLA-IS would considerably enrich and diversify this database, offering thus new opportunities to enlarge scientific collaborations.

To conclude, the OLA-IS success was made possible by three items. First thanks to the quality of its data and the presence of experts in different fields (taxonomy, chemistry, physics). Second, thanks to the traceability of the data, since metadata are associated to each data, detailing the protocols of acquisition, the material used and the responsible persons. Finally, thanks to the permanence and accessibility of the IS made possible by the commitment of the regular staff dedicated to its maintenance

\section{ACKNOWLEDGMENTS}

We thank CIPEL, CISALB, SILA and CCLA for their support in the OLA. We thank the AnaEE-F program and the national network ALLENVI for granting the OLA. ASTERS, EDF-CIH, Parc National des Ecrins, du Mercantour, de la Vanoise and 3CMA are thanked for funding data production. The GIS Lac Sentinelle is also thanked.

\section{REFERENCES}

Amoros C, 1984. [Introduction pratique à la systématique des organismes des eaux continentales françaises: Crustacés Cladocères]. Bulletin Mensuel Société Linnéenne de Lyon 53:72-145.
Anneville O, Dur G, Rimet F, Souissi S, 2018. Plasticity in phytoplankton annual periodicity: an adaptation to longterm environmental changes. Hydrobiologia 824:121-141.

Anneville O, Gammeter S, Straile D, 2005. Phosphorus decrease and climate variability: mediators of synchrony in phytoplankton changes among European peri-alpine lakes. Freshwater Biol. 50:1731-1746.

Anneville O, Leboulanger C, 2001. Long-term changes in the vertical distribution of phytoplankton biomass and primary production in Lake Geneva: a response to the olgotrophication. Atti Associazione Italiana Oceanologia Limnologia 14:25-35.

Anneville O, Molinero JC, Souissi S, Balvay G, Gerdeaux D, 2007. Long-term changes in the copepod community of Lake Geneva. J. Plankton Res. 29:49-59.

Anneville O, Molinero JC, Souissi S, Gerdeaux D, 2010. Seasonal and interannual variability of cladoceran communities in two peri-alpine lakes: uncoupled response to the 2003 heat wave. Journal of Plankton Research 32: 913-925.

CEN, 2006. Water quality - Guidance standard on the enumeration of phytoplankton using inverted microscopy (Utermöhl technique). European Committee for Standardisation EN 15204:1-42.

Civade R, Dejean T, Valentini A, Roset N, Raymond J-C, Bonin A, Taberlet P, Pont D, 2016. Spatial representativeness of environmental DNA metabarcoding signal for fish biodiversity assessment in a natural freshwater system. PLoS One 11:e0157366.

Clastre P, Pichot C, Chanzy A, 2018. Vocabulary for analysis and experimentation on terrestrial and aquatic ecosystems. Portail Data INRAE V3. doi: 10.15454/1. $4894016754286177 \mathrm{E} 12$.

Clobert J, Chanzy A, Le Galliard J-F, Chabbi A, Greiveldinger L, Caquet T, Loreau M, Mougin C, Pichot C, Roy J, SaintAndré L, 2018. How to integrate experimental research approaches in ecological and environmental studies: AnaEE France as an Example. Front. Ecol. Evol.-Agroecol. 6. doi: 10.3389/fevo.2018.00043

Dugan HA, Bartlett SL, Burke SM, Doubek JP, Krivak-Tetley FE, Skaff NK, Summers JC, Farrell KJ, McCullough IM, Morales-Williams AM, Roberts DC, Ouyang Z, et al., 2017a. Salting our freshwater lakes. Proceedings of the North American Society 114:4453-4458.

Dugan HA, Summers JC, Skaff NK, Krivak-Tetley FE, Doubek JP, Burke SM, Bartlett SL, Arvola L, Jarjanazi H, Korponai J, Kleeberg A, Monet G, et al., 2017b. Long-term chloride concentrations in North American and European freshwater lakes. Scientific Data 4:170101.

Dussart B, 1967. [Les Copépodes des eaux Continentales d'Europe Occidentale, Tome I: Calanoïdes et Harpacticoïdes].[Book in French]. Paris: 500 pp.

Dussart B, 1969. [Les Copépodes des eaux Continentales d'Europe Occidentale, Tome II : Cyclopoïdes et Biologie].[Book in French]. Paris: 292 pp.

Elbrecht V, Vamos EE, Meissner K, Aroviita J, Leese F, 2017. Assessing strengths and weaknesses of DNA metabarcoding-based macroinvertebrate identification for routine stream monitoring. Methods Ecol. Evol. 8:12651275. 
Feret L, Bouchez A, Rimet F, 2017. Benthic diatom communities in high altitude lakes: a large scale study in the French Alps. Intern. J. Limnol. 53:411-423.

Foley B, Jones ID, Maberly SC, Rippey B, 2012. Long-term changes in oxygen depletion in a small temperate lake: effects of climate change and eutrophication. Freshwater Biol. 57:278-289.

Godlewska M, Colon M, Jóźwik A, Guillard J, 2011. How pulse lengths impact fish stock estimations during hydroacoustic measurements at $70 \mathrm{kHz}$. Aquat. Living Resour. 24:71-78.

Guillard J, Vergès C, 2007. The repeatability of fish biomass and size distribution estimates obtained by hydroacoustic surveys using various sampling strategies and statistical analyses. Int. Rev. Hydrobiol. 92:605-617.

Gumy D, De Alencastro L, 2001. [Origine de la pollution du Léman par le chlorure. Rapport de la Commission International pour la Protection des Eau du Léman contre la Pollution].[Report in French]. Cipel, Lausanne.

Hebert P, Cywinska A, Ball SL, deWaard JR, 2003. Biological identifications through DNA barcodes. P. Roy. Soc. B 270:313-321.

Jacquet S, Barbet D, Cachera S, Crepin L, Espinat L, Frossard V, Girel C, Goulon C, Guillard J, Hamelet V, Hustache JC, Laine L, Naffrechoux E, Neasat J, Perney P, Rimet F, TranKhac V, 2018. [Suivi environnemental des eaux du lac du Bourget pour l'année 2017. (Rapport INRA-CISALBCALB)].[Report in Franch]. France.

Jacquet S, Domaizon I, Anneville O, 2014a. The need for ecological monitoring of freshwaters in a changing world: a case study of Lakes Annecy, Bourget, and Geneva. Environ. Monitor. Assess. 186:3455-3476.

Jacquet S, Kerimoglu O, Rimet F, Paolini G, Anneville O, 2014b. Cyanobacterial bloom termination: the disappearance of Planktothrix rubescens from Lake Bourget after restoration. Freshwater Biol. 59:2472-2487.

Jacquet S, Rimet F, Druart JC, 2014c. Composition and dynamics of the phytoplanktonic communities in 3 large and deep Western European Lakes: An outline of the evolution from 2004 to 2012, p. 131-150 In: Phytoplankton: Biology, Classification and Environmental Impacts. Nova Science Publishers, New York.

Kaiblinger C, Anneville O, Tadonleke R, Rimet F, Druart JC, Guillard J, Dokulil MT, 2009. Central European water quality indices applied to long-term data from peri-alpine lakes: test and possible improvements. Hydrobiologia 633:67-74.

Keck F, Vasselon V, Tapolczai K, Rimet F, Bouchez A, 2017. Freshwater biomonitoring in the Information Age. Front. Ecol. Environ. 15:266-274. doi:10.1002/fee.1490

Kermarrec L, Franc A, Rimet F, Chaumeil P, Humbert JF, Bouchez A, 2013. Next-generation sequencing to inventory taxonomic diversity in eukaryotic communities: a test for freshwater diatoms. Mol. Ecol. Res. 13:607-619.

Kraemer BM, Anneville O, Chandra S, Dix M, Kuusisto E, Livingstone DM, Rimmer A, Schladow SG, Silow E, Sitoki LM, Tamatamah R, Vadeboncoeur Y, et al., 2015. Morphometry and average temperature affect lake stratification responses to climate change. Geophys. Res. Lett. 42:4981-4988.

Le Moal M, Gascuel-Odoux C, Ménesguen A, Souchon Y,
Étrillard C, Levain A, Moatar F, Pannard A, Souchu P, Lefebvre A, Pinay G, 2019. Eutrophication: A new wine in an old bottle? Sci. Total Environ. 651:1-11.

Leach TH, Beisner BE, Carey CC, Pernica P, Rose KC, Huot Y, Brentrup JA, Domaizon I, Grossart H-P, Ibelings BW, Jacquet S, Kelly PT, et al., 2018. Patterns and drivers of deep chlorophyll maxima structure in 100 lakes: The relative importance of light and thermal stratification. Limnol. Oceanogr. 63:628-646.

Lefrançois E, Apothéloz-Perret-Gentil L, Blancher P, Botreau S, Chardon C, Crepin L, Cordier T, Cordonier A, Domaizon I, Ferrari BJD, Guéguen J, Hustache J-C, et al., 2018. Development and implementation of eco-genomic tools for aquatic ecosystem biomonitoring: the SYNAQUA FrenchSwiss program. Environ. Sci. Pollut. Res. 1-9.

Lepere C, Domaizon I, Debroas D, 2008. Unexpected importance of potential parasites in the composition of the freshwater small-eukaryote community. Appl. Environ. Microbiol. 74:2940-2949.

Madin J, Bowers S, Schildhauer M, Krivov S, Pennington D, Villa F, 2007. An ontology for describing and synthesizing ecological observation data. Ecol. Inform. 2:279-296.

Mangot JF, Domaizon I, Taib N, Marouni N, Duffaud E, Bronner G, Debroas D, 2013. Short-term dynamics of diversity patterns: evidence of continual reassembly within lacustrine small eukaryotes. Environ. Microbiol. 15:1745-1758.

Marcé R, George G, Buscarinu P, Deidda M, Dunalska J, Eyto E de, Flaim G, Grossart H-P, Istvanovics V, Lenhardt M, Moreno-Ostos E, Obrador B, et al., 2016. Automatic High Frequency Monitoring for Improved Lake and Reservoir Management. Environ. Sci. Technol. 50:10780-10794.

Mirtl M, Borer TE, Djukic I, Forsius M, Haubold H, Hugo W, Jourdan J, Lindenmayer D, McDowell WH, Muraoka H, Orenstein DE, Pauw JC, Peterseil J, Shibata H, Wohner C, Yu X, Haase P, 2018. Genesis, goals and achievements of Long-Term Ecological Research at the global scale: A critical review of ILTER and future directions. Sci. Total Environ. 626:1439-1462. doi: 10.1016/j.scitotenv. 2017.12.001

Molinero JC, Anneville O, Souissi S, Balvay G, Gerdeaux D, 2006. Anthropogenic and climate forcing on the long-term changes of planktonic rotifers in Lake Geneva, Europe. J. Plankton Res. 28:287-296.

Molinero JC, Anneville O, Souissi S, Lainé L, Gerdeaux D, 2007. Decadal changes in water temperature and ecological time series in Lake Geneva, Europe-relationship to subtropical Atlantic climate variability. Climate Rese. 34:15-23.

Monet G, Barbet D, Schellenberger A, Enrico G, Anache, 2020a. OLA's Database Datatypes modeling diagrams. Portail Data INRAE, V1. doi: 10.15454/OHXVJY.

Monet G, Barbet D, 2020b. Terms of Use of OLA-IS (Observatory of LAkes - Information System. Portail Data INRAE, V1. doi: 10.15454/HHN2GA.

Montuelle B, Clemens A, 2015. [Le tour des grands lacs alpins naturels en 80 questions].[Book in French]. Ed. Graie, Domaine scientifique de la Doua, Villeurbanne: 205 pp.

Nõges T, Anneville O, Guillard J, Haberman J, Järvalt A, Manca M, Morabito G, Rogora M, Thackeray SJ, Volta P, Winfield IJ, Nõges P, 2018. Fisheries impacts on lake ecosystem 
structure in the context of a changing climate and trophic state. J. Limnol. 77:46-61. doi: 10.4081/jlimnol.2017.1640

O'Reilly CM, Alin SR, Plisnier P-D, Cohen AS, McKee BA, 2003. Climate change decreases aquatic ecosystem productivity of Lake Tanganyika, Africa. Nature 424:766768.

O'Reilly CM, Sharma S, Gray DK, Hampton SE, Read JS, Rowley RJ, Schneider P, Lenters JD, McIntyre PB, Kraemer BM, Weyhenmeyer GA, Straile D, et al., 2015. Rapid and highly variable warming of lake surface waters around the globe. Geophys. Res. Lett. 42:10773-10781.

Padisak J, Crossetti LO, Naselli-Flores L, 2009. Use and misuse in the application of the phytoplankton functional classification: a critical review with updates. Hydrobiologia 621:1-19.

Pelletier JP, 1983. [Mesure de la production primaire en milieu aquatique: problèmes méthodologiques et éléments d'interprétation].[Article in French]. Rev. Franc. Sci. Eau 2:339-366.

Pelletier JP, Orand A, 1978. [Appareil de prélèvement d'un échantillon dans un fluide].[Patent in French]. Brevet d'invention 76.08579:

Perga M-E, Frossard V, Jenny J-P, Alric B, Arnaud F, Berthon V, Black J, Domaizon I, Giguet-covex C, Kirkham A, Magny M, Manca M, et al., 2015. High-resolution paleolimnology opens new management perspectives for lakes adaptation to climate warming. Front. Ecol. Evol. 3:117. doi: $10.3389 /$ fevo. 2015.00072

Pont D, Rocle M, Valentini A, Civade R, Jean P, Maire A, Roset N, Schabuss M, Zornig H, Dejean T, 2018. Environmental DNA reveals quantitative patterns of fish biodiversity in large rivers despite its downstream transportation. Sci. Rep. $8: 10361$

Reynolds CS, Huszar V, Kruk C, Naselli-Flores L, Melo S, 2002. Toward a functional classification of the freshwater phytoplancton. J. Plankton Res. 24:417-428.

Rimet F, Druart J-C, 2018. A trait database for Phytoplankton of temperate lakes. Ann. Limnolog. - Internat. J. Limnol. 54:18.

Rimet F, Druart JC, Anneville O, 2009. Exploring the dynamics of plankton diatom communities in Lake Geneva using emergent self-organizing maps (1974-2007). Ecol. Inform.4:99-110.

Rimet F, Vasselon V, A.-Keszte B, Bouchez A, 2018. Do we similarly assess diversity with microscopy and highthroughput sequencing? Case of microalgae in lakes. Org. Divers. Evol. 18:51-62.

Rivera S, Vasselon V, Jacquet S, Ariztegui D, Bouchez A, Rimet F, 2018. Metabarcoding of lake benthic diatoms: from structure assemblages to ecological assessment. Hydrobiologia 807:37-51.

Rose KC, Weathers KC, Hetherington AL, Hamilton DP, 2016. Insights from the Global Lake Ecological Observatory Network (GLEON). Inland Waters 6:476-482.

Schellenberger A, Monet G, Barbet D, Maurice D, Enrico G, Fiocca A, 2019a. Software Architecture of the OLA Observatory Information System for Lake Environmental Research. Portail Data INRAE V2. doi: 10.15454/ VBWYWG.
Schellenberger A, Tcherniatinsky P, Yayende-Guedoka VJ, Yahiaoui R, Maurice D, Monet G, 2019b. Software architecture for environnemental research observatories information systems: central component. Portail Data INRAE V1. doi: 10.15454/QJJJZU.

Sharma S, Gray DK, Read JS, O'Reilly CM, Schneider P, Qudrat A, Gries C, Stefanoff S, Hampton SE, Hook S, Lenters JD, Livingstone DM, et al., 2015. A global database of lake surface temperatures collected by in situ and satellite methods from 1985-2009. Sci. Data 2:150008.

Shiklomanov I, 1993. World fresh water resources. In: P. H. Gleick (ed.), Water in crisis: A guide to the world's fresh water resources. Oxford University Press, New York.

Steemann-Nielsen E, 1952. The use of radio-active carbon (C14) for measuring organic production in the sea. ICES J. Mar. Sci. 18:117-140.

Stemberger R, 1979. A guide to rotifers of the Laurentian Great Lakes. Scholar's Choice, Cincinnati: 186 pp.

Tadonleke RD, Lazzarotto J, Anneville O, Druart JC, 2009. Phytoplankton productivity increased in Lake Geneva despite phosphorus loading reduction. J. Plankton Res. 31:1179-1194.

Taib N, Mangot JF, Domaizon I, Bronner G, Debroas D, 2013. Phylogenetic affiliation of SSU rRNA genes generated by massively parallel sequencing: New insights into the freshwater protist diversity. PLoS One 8:1-13.

Tapolczai K, Anneville O, Padisak J, Salmaso N, Morabito G, Zohary T, Tadonleke RD, Rimet F, 2015. Occurrence and mass development of Mougeotia spp. (Zygnemataceae) in large, deep lakes. Hydrobiologia 745:17-29.

Taranu ZE, Gregory $\square$ Eaves I, Leavitt PR, Bunting L, Buchaca T, Catalan J, Domaizon I, Guilizzoni P, Lami A, McGowan S, Moorhouse H, Morabito G, et al., 2015. Acceleration of cyanobacterial dominance in north temperate-subarctic lakes during the Anthropocene. Ecol. Lett. 18:375-384.

Utermöhl H, 1958. [Zur Vervollkommung der quantitative Phytoplankton Methodik].[Article in German]. Mitteil. Internat. Verein. Theor. Angew. Limnol. 9:1-38.

Vasselon V, Rimet F, Tapolczai K, Bouchez A, 2017. Assessing ecological status with diatoms DNA metabarcoding: Scaling-up on a WFD monitoring network (Mayotte island, France). Ecol. Ind. 82:1-12.

Voigt M, Koste W, 1978a. Rotatoria, I: Textband. Berlin, Stuttgart, Germany: 673 pp.

Voigt M, Koste W, 1978b. Rotatoria, II: Tafelband. Berlin, Stuttgart, Germany: 237 pp.

Weyhenmeyer GA, Hartmann J, Hessen DO, Kopáček J, Hejzlar J, Jacquet S, Hamilton SK, Verburg P, Leach TH, Schmid M, Flaim G, Nõges T, et al., 2019. Widespread diminishing anthropogenic effects on calcium in freshwaters. Sci. Rep. 9:1-10.

Wohner C, Peterseil J, Poursanidis D, Kliment T, Wilson M, Mirtl M, Chrysoulakis N, 2019. DEIMS-SDR - A web portal to document research sites and their associated data. Ecol. Inform. 5:15-24.

Yule DL, Evrard LM, Cachera S, Colon M, Guillard J, 2013. Comparing two fish sampling standards over time: largely congruent results but with caveats. Freshwater Biol. 58:2074-2088. 